\title{
To Cheat or not to Cheat? Sex Differences and Academic Performance as Factors of Cheating Behavior
}

\author{
Ibnu Hadjar \\ Universitas Islam Negeri Walisongo \\ Semarang \\ email: ibnu.kuliah@gmail.com
}

\begin{abstract}
Cheating behavior at higher education is a global phenomenon since it is found at any university in any country. This study is to examine whether sex differences and academic performance reflect the different likelihood of doing cheating among students. Using a questionnaire, data were collected from 436 students selected from different semesters and study programs in all faculties at a State Islamic University. Data were analyzed by using logistic regression, both separately and simultaneously. The results of data analysis revealed that male students tend to be more likely to do cheating categories than that of their female counterparts. It also found that academic performance affects negatively the likelihood of students to cheat in three categories of cheating behavior, but not in the other three. There is no stimulant effect of sex and academic performance on the likelihood of all categories of cheating behaviors. In other words, the effect of sex differences is not depended on academic performance and vice versa.
\end{abstract}

\section{Keywords: cheating behavior; sex differences; academic performance; probability}

\begin{abstract}
Abstrak: Perilaku mencontek di lingkungan perguruan tinggi merupakan fenomena global karena bisa ditemukan di perguruan tinggi manapun dan di negara manapun. Penelitian ini bertujuan untuk menguji apakah perbedaan jenis kelamin dan hasil belajar mencerminkan kemungkinan yang berbeda dalam mencontek di kalangan mahasiswa. Denan menggunakan kuesener, data dikumpulkan dari 436 mahasiswa yang dipilih dari berbagai semester dan program studi di semua fakultas yang ada di sebuah Universitas Islam Negeri. Hasil analisis data menngungkap bahwa mahasiswa laki-laki cenderung lebih besar peluangnya untuk melakukan semua kategori perilaku mencontek dari pada rekan perempuan mereka. Juga ditemukan bahwa hasil belajar memengaruhi secara negatif peluang siswa untuk mencontek dalam tiga kategori perilaku mencontek, tetapi tidak pada tiga lainnya. Tidak ada efek simultan dari jenis kelamin dan hasil belajar pada peluang untuk melakukan semua kategori perilaku curang. Dengan kata lain, pengaruh perbedaan jenis kelamin tidak tergantung pada hasil belajar, dan sebaliknya.
\end{abstract}

Kata Kunci: perilaku mencontek; perbedaan jenis kelamin; capaian akademik; probabilitas 


\section{A. Introduction}

Cheating is a serious issue for higher education, where ones' reputations can be gained inappropriately. ${ }^{1}$ It is a global phenomenon that occurs almost in every country ${ }^{2}$ since it is a complex issue that is neither confined to a certain georaphical hemisphare nor a certain culture. ${ }^{3}$ Gradually, it has erroded highereducation system, which involeved students and faculty members. It is becoming epidemic and is much worse than it was in the past. ${ }^{4}$ For students, it may occurs in relation to any course work, such as exam, home work, project, and research assignment.

It is commonly understood that academic cheating is the use of illegal actions since it is a shortcut to attain achievement in the study. ${ }^{5}$ It is one of academic dishonesty which usually refers to behaviors such as copying others' work in exams, homework, assignments, unauthorized cooperation with others, and plagiarism. ${ }^{6}$ Although the act is unacceptable, both morally and legally, it is easily found in almost any university or college. Harding and his colegues, for example, find more than $45 \%$ of university students admit to frequently being dishonest.7 Hamani and his collegues also find that $70 \%$ of students have cheated at least once during their university studies. ${ }^{8}$

\footnotetext{
${ }^{1}$ Jenny Moon, Academic dishonesty, plagiarism and cheating: A self-instruction unit for postgraduate students, 2006, accessed on October 22, 2018, in http://wwwold.hud.ac.uk/ schools/hhs/teaching_learning/plagiarism_handout3.pdf.

${ }^{2}$ W. Decoo, "How to Break that Cheating Art," Times Higher Education Supplement, 2002, February, 1526, 1 .

${ }^{3}$ Diana Starovoytova and Saul Namango, "Factors Affecting Cheating-Behavior at UndergraduateEngineering," Journal of Education and Practice 7, no. 31 (2016): 66.

4 J. M. Lang Cheating Lessons: Learning from Academic Dishonesty (Cambridge: Harvard University Press, 2013), 2.

${ }^{5}$ Ramon Cladellas, Mercè Clariana Muntada, Badia Martín, and Concepción Gotzens, "Academic Cheating and Gender Differences in Barcelona (Spain)," Summa Psicológica UST 10, no. 1 (2013): 65-72, https://doi.org/10.18774/448x.2013.10.37

${ }^{6}$ Lene Arnett Jensen, Jeffrey Jensen Arnett, Sue S. Feldman, Elizabeth E. Cauffman. “It's Wrong, but Everybody Does It: Academic Dishonesty among High School and College Students," Contemporary Educational Psychology 27, no. 2 (2002): 209-28, https://doi.org/10.1006/ceps.2001.1088.

${ }^{7}$ Trevor S. Harding, Matthew J. Mayhew, Cynthia J. Finelli, and Donald D. Carpenter, "The Theory of Planned Behavior as a Model of Academic Dishonesty in Engineering and Humanities Undergraduates," Ethics \& Behavior 17, no. 3 (2007): 255-279, https://doi.org/10.1080/ 10508420701519239

${ }^{8} J a o u h a r$ Hamani, Nasr Chalghaf, Habib Maaloul, and Fairouz Azaiez, "The Exam Cheating among Tunisian Students of the Higher Institute of Sport and Physical Education of Sfax," Journal of Humanities and Social Science 15, no. 6 (2013): 90-95.
} 
Witherspoon, Maldonado, and Lacey find $79.7 \%$ of their respondents had cheated at least once while their studyin college. ${ }^{9}$ More recent study by the researcher ${ }^{10}$ finds that almost all students experiencing cheating, at least in one form or another.

Basically, academic cheating is an individual act strongly relates to the individual's morality and ethical compass. It has been studied in relation to students' characteristics, the most common one is gender. Previous studies in relation to gender differences in academic cheating have produced mixed findings. ${ }^{11}$ Reviewing previous studies, Whitley find that male and female are almost equal in their desire to cheat.12 Meanwhile, McCabe and Trevino find that the intence of females to cheat have increased over the past years in the level of relatively similar to males'. Based on their reviews on previous research, Gibson et. al. Conclude that males students tend to commit more academically dishonest behavior than their female counterparts.

Further studies find that male students are more likely to cheat because they have more permissive attitudes towards cheating than their female counterparts. It is also because of differences in a set of social mechanisms related to gender, such as shame, embarrassment, self-control. ${ }^{13}$ Differences between male and female also relate to differences in concern over ethics and perceptions about academic dishonesty. ${ }^{14}$ That is, females perceive academic dishonesty to be a more significant problem than do males. They also implement controls over academic dishonestly more frequently than do males.

\footnotetext{
${ }^{9}$ Michelle Witherspoon, Nancy Maldonado, Candace H. Lacey, "Academic Dishonesty of Undergraduates: Methods of Cheating," Paper presented at the Annual Meeting of the American Educational Research Association, May 2010, Denver, Colorado.

${ }^{10}$ Ibnu Hadjar, "The Effect of Religiosity and Perception on Academic Cheating among Muslim Students in Indonesia," Journal of Education and Human Development 6, no. 1 (2017): 139-147, https://doi.org/10.15640/jehd.v6n2a15.

${ }^{11}$ Hamani, Chalghaf, Maaloul, and Azaiez, "The Exam Cheating among Tunisian Students of the Higher Institute of Sportand Physical Education of Sfax."

${ }^{12}$ Bernard E. Whitley Jr., "Factors Associated with Cheating among College Students: A Review," Research in Higher Education 39, no. 3 (1998): 235-274.

${ }^{13}$ Yu Niiya, Robert Ballantyne, Michael S. North, Jennifer Crocker, "Gender, Contingencies of SelfWorth, and Achievement Goals as Predictors of Academic Cheating in a Controlled Laboratory Setting," Basic and Applied Social Psychology30, no. 1 (2008): 76-83.

${ }^{14}$ Camillo Lento, Naqi Sayed, \& Merridee L. Bujaki, "Perceptions of Student Academic Dishonesty by Male and Female Accounting Faculty: Incidents and Responses," a paper presented at Canadian Academic Accounting Association (CAAA) Annual Conference, 2016, in SSRN:https:// ssrn.com/abstract=2713952 or http://dx.doi.org/10.2139/ssrn. 2713952
} 
Ibnu Hadjar

Students' cheating has also been extensively studied in relation to academic achievement. The studies find that both variables have negative relationship. ${ }^{15}$ That is, students with lower achievement tend to be more likely to cheat than those with higher achievement. However, no any level of achievers, even the highest ones, is free from the likelihood of cheating. It because, as Finn and Frone's finding, 16 cheating is done by students at all level of academic achievement, even from elementary schools to colleges. For the lower achievers, the act of cheating rises in relation to school identification. While for the higher achievers, the rising of cheating relates to low academic self-efficacy. In other words, students highly motivated to achieve a good grade are more likely to cheat than those motivated to solely gain knowledge.

In the context of higher education, cheating is a complex-behavior affected by multiple-situational contexts and individual qualities. Studies on academic cheating involves a wide range of behaviours, such as taking, giving, or receiving information from others, use of forbidden materials or information, and circumventing the process of assessment. It has also been studied by researchers in relation to many factors, such as religiosity, ${ }^{17}$ academic performance, ${ }^{18}$ demography and academic orientation, ${ }^{19}$ motivation, ${ }^{20}$ anxiety about the future, ${ }^{21}$ and moral reasoning and religion. ${ }^{22}$

\footnotetext{
${ }^{15}$ Helen A. Klein, Nancy M. Levenburg, Marie McKendall, and William Mothersell, "Cheating during the College Years: How Do Business School Students Compare?" Journal of Business Ethics 72, no. 2 (2007): 197-206. Robert T. Burrus, Kim Marie McGoldrick and Peter W. Schuhmann, "Self-reports of student cheating: Does a definition of cheating matter?" The Journal of Economic Education 38, no. 1 (2007): 3-16.

${ }^{16}$ Kristin Voelkl Finn and Michael R. Frone, "Academic Performance and Cheating: Moderating Role of School Identification and Self-Efficacy," The Journal of Educational Research 97, no. 3 (2004): 115121, https://doi.org/10.3200/JOER.97.3.115-121.

${ }^{17}$ Hadjar, "The Effect of Religiosity and Perception on Academic Cheating among Muslim Students in Indonesia."

${ }^{18}$ Finn and Frone, "Academic Performance and Cheating: Moderating Role of School Identification and Self-Efficacy."

${ }^{19}$ Helen Marsden, Marie Carroll and James T. Neill, "Who cheats at university? A self-report study of dishonest academic behaviours in a sample of Australian university students," Australian Journal of Psychology57, no. 1(2005):1-10, https://doi.org/10.1080/00049530412331283426

${ }^{20}$ David Rettinger and Agustus Jordan, "The Relations Among Religion, Motivation, and ollege Cheating: A Natural Experiment," Ethics \& Behavior 15, no. 2 (2005): 107-129, https://doi.org/ 10.1207/s15327019eb1502_2.

${ }^{21}$ David Callahan, The Cheating Culture: Why More Americans are Doing More to Get Ahead (Orlando: Harcourt, 2005).
} 
The studies treat the cheating as a single variable so that it can not uncover various cheating behaviors in relation to the factors. Most of them also treat it as a continum variabel in term of the intensity to do it. As it is one of ethics and moral issues, it needs to be treated as a binary variable, in term of whether or not a subject involve in various cheating behaviors.

This study aims to investigate the effect of sex diffrences and academic achevement on the likelihood of doing a certain cheating behavior among students at a State Islamic University in Indonesia. Specifically, it is intended to test a hypothesis: sex diferences and academic performance affect the likelihood of students' cheating behaviors,' both separately and simultaneously.

\section{B. Methods}

Participants were 436 undergraduate student at Walisongo Islamic State University, Semarang, Indonesia. The participants were selected from four different class levels with balanced distribution (ranged from $22.6 \%$ to $25.9 \%$ ) and from all (eight) faculties in the university. Of the participants, $61.2 \%$ were female, reflecting the composition of the student body at the university, which are dominated by females. They ranged in age from 18 to 23; the average age is about 20 years. It is expected that the sample is representative of the student body in the university.

Data were collected by using a questionnaire, which was especially designed for this study. In responding to the questionnaire, the subjects were asked to complete it anonymously to guarantee that their identities are not recognized so that they would response openly and honestly. The questionnaire was designed in accordance with the characteristics of each variable.

Cheating behavior is defined as an unhonest behavior in doing response to academic assigment/task and exams during studying at the university. The questionnaire consisted of 6 questions regarding whether or not the subject ever cheated during the last year of they study at the university. The questions reflected six categories of chetaing behavior, namely copying a friend's homework (CFH), copying a friend's work in an exam (CFWE), making a cheat

\footnotetext{
${ }^{22}$ Elizabeth Leistler Bruggeman and Kathleen J. Hart, "Cheating, Lying, and Moral Reasoning by Religious and Secular High School Students," The Journal of Educational Research 89, no. 6 (1996): 340344.
} 
sheet for an exam (MCSE), copying a cheat sheet in an exam (CCSE), using a friend's paper for fulfilling a course assignment (CFPFCA), and citing references in writing without modification. The variables were treated as binary so that their respone were scored 0 for "never" and 1 for "ever" doing the behavior, at least once during their study at the university. Since the sensitivity of dishonest behaviours, the questionnaire is anonymous self-report.

Sex was differenciated into female and male. In this study, sex was treated as binary variable, in which males were treated as the basis of the analysis so that they were given a score of 0 , while females were given a score of 1 .

Academic performance were assessed with students' grades achieved for the courses they had studied. Since all participants had taken many courses during their studies, the grades were averaged so that data were in the form of average values of all courses, that was grade point average or GPA. In accordance with the system used in the university, the GPA could be range from 0.0 to 4.0 .

In accordance with the characteristics of criteria variable, data were analyzed statistically by using logistic regression. ${ }^{23}$ It was used to test the model for the likelihood or probability of event of the binary dependent variable (ever or never doing a stated cheating behavior) as affected by the score of the independent variables (sex and academic performance). In this study, three logistic regression models were used to uncover the effects of the independent variables. The most important of output of the analysis is coeficient regression or odds its level of significance. The result is decided to be significant if $p \geq 05$. The analysis was performed by using SPSS 22.0 program. ${ }^{24}$ The logistic model based on the outputs was, then, developed as the followings:

$$
\begin{array}{ll}
\text { Model for separated factors } & : \operatorname{Logit}\left(p_{[\mathrm{Y}=1]}\right)=\beta_{0}+\beta \mathrm{X} \\
\text { Model for simultaneous factors } & : \operatorname{Logit}\left(p_{[\mathrm{Y}=1]}\right)=\beta_{0}+\beta_{1} \mathrm{X}_{1}+\beta_{2} \mathrm{X}_{2} .
\end{array}
$$

And the likelihood/probability for cheating behavior is:

$$
p=\mathrm{e}^{\operatorname{Logit}(\mathrm{p}[\mathrm{Y}=1])} /\left\{1+\mathrm{e}^{\operatorname{Logit}(\mathrm{p}[\mathrm{Y}=1])}\right\}
$$

${ }^{23}$ Ibnu Hadjar, Statistik untuk Ilmu Pendidikan, Sosial, dan Humaniora (Bandung: Rosda Karya, 2019), 203-242. Petek Așkar, Yasemin Koçak Usluel, and Filiz Mumcu, "Logistic Regression Modeling for Predicting Task-Related ICT Use in Teaching," Educational Technology and Society 9, no. 2 (2006) 141151.

${ }^{24}$ IBM Corp., IBM SPSS Statistics for Windows, Version 22.0 (Armonk, NY: IBM Corp, 2013). 
In order to give an idea about the tendencies of scores of each variables, data were analysed descriptively to calculate frequency (for binary variable) and centrality and variability (for continuous variables). The statistical calculation was done with the help of W-Stats 2.0 program. ${ }^{25}$

\section{Results}

The results of descriptif analysis show that for the past year, almost all participants involved in academic cheating. 92.5\% them have experienced cheating, at least in one of six categories of cheating behaviors and only $7.5 \%$ of paticipants have never cheated.. Among the cheaters, $10.6 \%$ experienced doing all (six) cattegories, while the other $11 \%$ experienced doing only one category. This percentage of doing cheating is higher for male (94.3\%) than that for female $(91,3 \%)$. Furthermore, the percentage of those experiencing cheating varies from one category to another. A summary of the results of descriptive analysis of the data is presented in the following Table 1.

\section{Table 1.}

Percentage of doing cheating and descriptive statistics of Academic achievement based on sex

\begin{tabular}{|c|c|c|c|}
\hline Variable & $\begin{array}{c}\text { Male } \\
(N=169)\end{array}$ & $\begin{array}{l}\text { Female } \\
(\mathrm{N}=267)\end{array}$ & $\begin{array}{l}\text { Total } \\
(\mathrm{N}=436)\end{array}$ \\
\hline Cheating behavior (at least one form) & $94.3 \%$ & $91.3 \%$ & $92.5 \%$ \\
\hline Copying a friend's homework (CFH) & $78.1 \%$ & $68.2 \%$ & $72.0 \%$ \\
\hline Copying a friend's work in an exam (CFWE) & $71.0 \%$ & $61.0 \%$ & $64.9 \%$ \\
\hline Making a cheat sheet for an exam (MCSE) & $40.2 \%$ & $30.0 \%$ & $33.9 \%$ \\
\hline Copying a cheat sheet in an exam CCSE) & $47.9 \%$ & $30.0 \%$ & $36.9 \%$ \\
\hline $\begin{array}{l}\text { Using a friend's paper for fulfilling a course } \\
\text { assignment (UFPFCA) }\end{array}$ & $36.7 \%$ & $30.7 \%$ & $33.0 \%$ \\
\hline $\begin{array}{l}\text { Citing references in writing without any } \\
\text { modification (CRWWAM) }\end{array}$ & $75.7 \%$ & $70.0 \%$ & $72.2 \% 7$ \\
\hline \multicolumn{4}{|l|}{ Academic acheivement/GPA } \\
\hline Mean & 3.48 & 3.58 & 3.55 \\
\hline Standard Deviation & 0.26 & 0.23 & 0.25 \\
\hline
\end{tabular}

${ }^{25}$ Ibnu Hadjar, W-Stats: Program Aplikasi Statistik Walisongo (Semarang: UIN Walisongo, 2016). 
The table shows that the number of students' involvement varies from one cheating behavior to another, both for male and female. In the overall behaviors, male students consistently tend to have higher percentage of doing cheating than females do. The difference in tendency to cheat between male and female students also varies, ranging from $5.7 \%$ (citing references in writing without any modification) to $17.9 \%$ (copying a cheat sheet in an exam). The highest involvement of students in cheating is citing references in writing without any modification (78.1\% for male and $68.2 \%$ for female), slightly higher than that by copying a friend's homework $75.7 \%$ for male and $70.0 \%$ for female). Almost two third of the subjects (64.9\%, in which percentege of males involved is $10 \%$ higher than that of females) cheat by copying a friend's work in exam. The lowest percentage of students' involvement in cheating is using a friend's paper for fulfilling a course assignment $(36.7 \%$ for males and $6 \%$ less for females).

The results of descriptive analysis also reveal differences between male and female participants in their academic achievement. Contrary to the involement in cheating behaviors, females have higher academic achievement (in term of cumulative Grade Point Average/GPA) than male do. In the average, females achieve GPA of 3.58 (very good), while males achieve GPA of 3.48 (good). Although achieving higher GPAs, females tend to be more homogeneous than males do in their GPAs ( $\mathrm{SD}=.23$ and $\mathrm{SD}=.26$ respectively).

The results of descriptive analyses indicate that male participants have higher tendency to involve in cheating behaviors than female ones do. However, they achieve lower learning outcomes/GPA on the courses they had taken during the past academic year. Is the difference of the involvement in all categories of cheating behaviors between male and female students significant or just by chance?

Data analyses by using logistic regression with sex and academic achievement as predictors were done, both separately and simultaneously. The analysis were done in three models of logits, model 1 (by sex, separately), model 2 (by academic achievemet, separately) and model 3 (by sex and academic achievement simultaneously). The results of the analyses (especially the coefficient of log odds and its level of significance) are presented in the Table 2. 
Table 2.

Binary logistic regression coeficients/log odds of doing a certain cheating behavior and its level of significance $(p)$ by sex and GPA/academic achievement

\begin{tabular}{llccc}
\hline Criteria/Cheating behavior & Predictor & Model 1 & Model 2 & Model 3 \\
\hline $\begin{array}{l}\text { Copying a friend's homework } \\
\text { (CFH) }\end{array}$ & Constant & $1.272(<.001)$ & $4.477(.009)$ & $4.120(.016)$ \\
& Sex & $-.511(.025)$ & - & $-.434(.062)$ \\
& GPA & - & $-.992(.038)$ & $-.814(.091)$ \\
\hline Copying a friend's work in an & Constant & $.896(<.001)$ & $2.869(.058)$ & $2.563(.090)$ \\
exam (CFWE) & Sex & $-.446(.034)$ & - & $-.400(.063)$ \\
& GPA & - & $-.634(.135)$ & $-.478(.267)$ \\
\hline Making a cheat sheet for an & Constant & $-.396(.012)$ & $2.751(.053)$ & $2.498(.082)$ \\
exam (MCSE) & Sex & $-.453(.028)$ & - & $-.373(.076)$ \\
& GPA & - & $-.966(.016)$ & $-.831(.043)$ \\
\hline Copying a cheat sheet in an & Constant & $-.083(.590)$ & $2.322(.098)$ & $1.836(.199)$ \\
exam (CCSE) & Sex & $-.766(<.001)$ & - & $-.714(.001)$ \\
& GPA & - & $-.807(.042)$ & $-.551(.177)$ \\
\hline Using a friend's paper for & Constant & $-.679(.643)$ & $-.468(.746)$ & $-.679(.643)$ \\
fulfilling a course & Sex & $-.268(.197)$ & - & $-.272(.199)$ \\
assignment (UFPFCA) & GPA & - & $-.067(.868)$ & $.038(.927)$ \\
\hline Citing references in writing & Constant & $1.138(<.001)$ & $1.632(.294)$ & $1.423(.360)$ \\
without modification (CRW) & Sex & $-.289(.196)$ & - & $-.281(.218)$ \\
& GPA & - & $-.190(.663)$. & $-.082(.854)$ \\
\hline
\end{tabular}

Based on the results of logistic regression analyses, as presented by model 1 in the table (isolated from academic achievement), sex difference has significant effect $(p<.10)$ on the likelihood of students' involvement in 4 cheating behaviors. However, one of them (copying a cheat sheet in an exam) has no significant constant coefficients ( $p>.10)$. Therefore, sex is only appropriate for predicting three cheating behaviors, namely: copying a friend's homework $\left(\beta_{0}=1.272[\mathrm{p}=.<001] ; \beta_{1}=-.511[\mathrm{p}=.025]\right)$, copying a friend's work in an exam $\left(\beta_{0}=-.896[\mathrm{p}=<.001] ; \beta_{1}=-.446[\mathrm{p}=.034]\right)$, and making a cheat sheet $\left(\beta_{0}\right.$ $\left.=-.396[\mathrm{p}=.012] ; \beta_{1}=-.453[\mathrm{p}=.028]\right)$. With negative coefficient of the log odds $\left(\beta_{1}\right)$, the results indicate that female students tend to have lower likelihood in involving in the cheating behaviors than those of males do. 
Although sex has signicicant effect on copying a cheat sheet in an exam $(p<10)$, its constant coefficients is not significant $(p>10)$. The effect of sex differences is also not significant on the other cheating behaviors (copying a cheat sheet in an exam, citing references in writing without modification, and using a friend's paper for fulfilling a course assignment). It indicates that male and female students have no different likelihood in involving in the last three cheating behaviors.

The significant results enable to use sex differences to develop a logistic model to predict the likehood of students to cheat by doing the three cheating behaviors:

1. Copying a friend's homework:

$$
\operatorname{Logit}_{(\mathrm{Y}=1)}=\beta_{0}+\beta_{1}\left(\mathrm{X}_{1}\right)=1.272-.511(\mathrm{sex})
$$

2. Copying a friend's work in an exam:

$$
\operatorname{Logit}_{(\mathrm{Y}=1)}=\beta_{0}+\beta_{1}\left(\mathrm{X}_{1}\right)=.896-.446(\mathrm{sex})
$$

3. Making a cheat sheet for an exam:

$$
\operatorname{Logit}_{(\mathrm{Y}=1)}=\beta_{0}+\beta_{1}\left(\mathrm{X}_{1}\right)=-.396-.453(\mathrm{sex})
$$

Based on the logits, it is possible to predict the likelihood or probablity of each sexes to do each of the cheating behaviors by transforming the logits into a

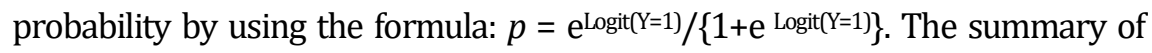
the results of the transformation is presented in the following Table 3 . Based on the table 3 , although both sexes are involved in the three cheating behaviors in fulfilling academic task or exam, their levels of probability to cheat are different. Male students tend to have higher probability to cheat than females do. Therefore, it is concluded that sex differences affect the probability or likelihood to do some (three) cheating behaviors, but not the other ones (three).

Table 3.

Differences in probability of doing certain cheating behaviors between male and female students

\begin{tabular}{lcc}
\hline \multicolumn{1}{c}{ Cheating behavior } & \multicolumn{2}{c}{ Probability for } \\
& Female & Male \\
\hline Copying a friend's homework & 0,68 & 0,78 \\
Copying a friend's work in an exam & 0,61 & 0,71 \\
Making a cheat sheet for an exam & 0,30 & 0,40 \\
\hline
\end{tabular}


In model 2 (isolated from sex), the academic achievement or GPA affect significantly $(\mathrm{p}<.10)$ only on three out of six cheating behaviors, namely copying a friend's homework $\left(\beta_{0}=4.477\right.$ [ $\left.\mathrm{p}=.009\right] ; \beta_{2}=-.992$ [p=.038]), making a cheat sheet for an exam ( $\left.\beta_{0}=2.751[\mathrm{p}=.053] ; \beta_{2}=-.966[\mathrm{p}=.016]\right)$, and copying a cheat sheet in an exam $\left(\beta_{0}=2.322[\mathrm{p}=.098] ; \beta_{2}=-.807[\mathrm{p}=.042]\right)$. The negative value of the log odds indicate that the higher the GPA achieved by a student, the lower the probability to cheat by doing the cheating behaviors.

Furthermore, unlike on the previous cheating behaviors, academic achievement has no significant effect ( $p>10)$ on the other three cheating behaviors. It means that the variation of academic achievement of students is not consistently followed by sistematic probability to do the cheating behaviors. In summary, academic achievement has significant effect on the students' likelihood to copy a friend's homework, making a cheat sheet for an exam, and Copying a cheat sheet in an exam, but it has no significant effect on the other cheating behaviors.

Using the significant results of the analysis, it is reasonable, therefore, to make a model of logits for the effect of academic achievement/GPA on each of the cheating behavior as Model 2, the following:

1. Copying a friend's homework:

$$
\operatorname{Logit}_{(\mathrm{Y}=1)}=\beta_{0}+\beta_{2}\left(\mathrm{X}_{2}\right)=4.477-.992(\mathrm{GPA}) \text {. }
$$

2. Making a cheat sheet for an exam:

$$
\operatorname{Logit}_{(\mathrm{Y}=1)}=\beta_{0}+\beta_{2}\left(\mathrm{X}_{2}\right)=2.751-.966(\mathrm{GPA}) \text {. }
$$

3. Copying a cheat sheet in an exam:

$$
\operatorname{Logit}_{(\mathrm{Y}=1)}=\beta_{0}+\beta_{2}\left(\mathrm{X}_{2}\right)=2.322-.807(\mathrm{GPA}) \text {. }
$$

Based on the logits, it is possible to predict the probablity of a student achieving a certain value of GPA to each cheating behavior by transforming the logits to a probability by using the formula: $p=\mathrm{e}^{\log i t(\mathrm{Y}=1)} /\left(1+\mathrm{e}^{\mathrm{Logit}[\mathrm{Y}=1]}\right)$. The summary of the results of the transformation of different values of academic achievement/GPA between 2.0 to 4.0 is visually presented in the Figure 1 .

The Figure 1 shows that academic achievement correlates negatively with the probability of a student to cheat by copying a friend's homework, making a cheating sheet for an exam, and copying a cheating sheet in an exam. It means that the higher the GPA, the less likely to do such cheating behaviors. 


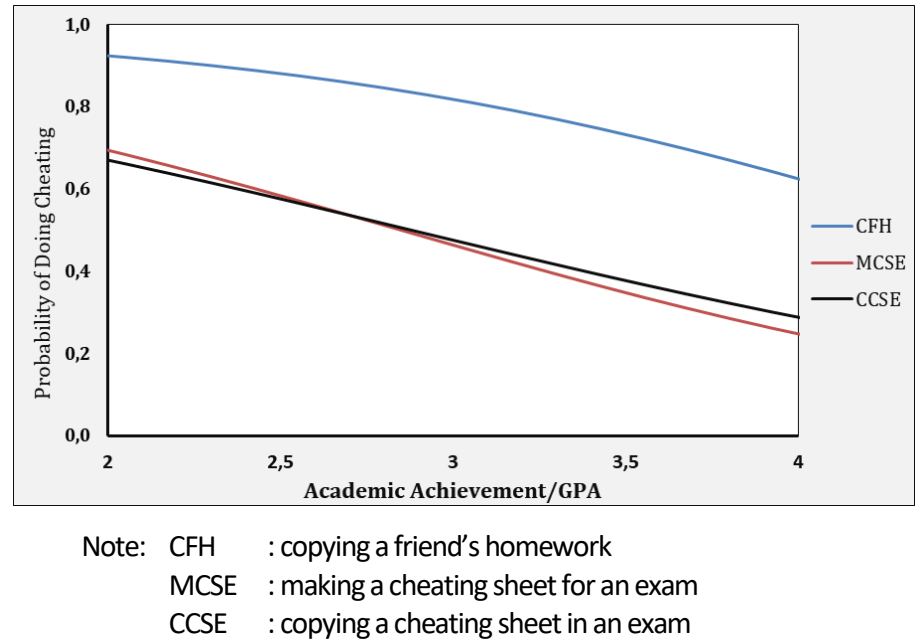

Figure 1.

Probability to do a certain cheating behavior based on academic performance/GPA

The probability of copying a friend's homework in any point of GPA is much higher than that of the other two cheating behaviors. The probability for the lowest achiever/participant (with GPA=2.2) and the highest achiever $(\mathrm{GPA}=4.0)$ is about .91 and .62 in copying a friend's homework; 65 . and .25 in making a cheating sheet for an exam; .63 and .29 in copying a cheating sheet in an exam. It indicates that cheating is not monopolyzed by the lower achiever, but also by higher achievers, although the probablity to do so is decreasing.

In Model 3, simultaneously sex and academic achievement have significant effect ( $\mathrm{p} \geq 10$ ) on the likelihood of a student to cheat by copying a friend's homework $\left.\left(\beta_{0}=4.120[\mathrm{p}=.016] ; \beta_{1}=-.434[\mathrm{p}=.062]\right) ; \beta_{2}=-.814[\mathrm{p}=.091]\right)$. However, both predictors are simultaneously not signficant ( $p>10$ ) in affecting any other category of cheating behaviors. It indicates that the effect of sex on copying a friend's homework is dependent upon academic achievement, and vice versa. In other words, although consistently male students have a higher probability than their female counterpart, their probabilities to cheat are dependent upon the level of academic achievement. Based on this finding, it enables to predict the likelihood of a student to copy a friend's homework by using the following model: 
1. Logistic model for female:

$$
\operatorname{Logit}_{(\mathrm{Y}=1)}=\beta_{0}+\beta_{1} \mathrm{X}_{1}+\beta_{2} \mathrm{X}_{2}=4.120-.434-.814(\mathrm{GPA})
$$

2. Logistic model for female:

$$
\operatorname{Logit}_{(\mathrm{Y}=1)}=\beta_{0}+\beta_{2} \mathrm{X}_{2}=4.120-.814(\mathrm{GPA})
$$

Based on the logits, it is possible to calculate the probability for each sex achieving a certain value of GPA by transforming the logits into a probability, pvalue, using the following formula:

$$
p=\mathrm{e}^{\mathrm{Logit}(Y=1)} /\left(1+\mathrm{e}^{\operatorname{Logit}[Y=1]}\right)
$$

If the values of each sex for each point in the range of GPE between 2.0 to 4.0 transformed into a probability value, the results can be visualized in the Figure 2.

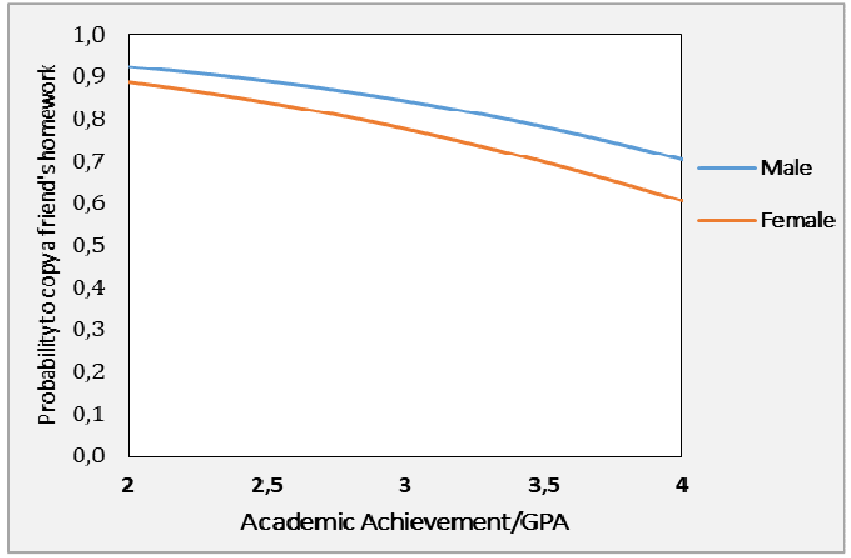

Figure 2.

Probability to cheat by copying a friend's homework based on academic performance/GPA and sex

The figure shows that whatever the value of GPA achieved by students, they have a probability to cheat, although it is decreasing whenever the GPA increases. It also shows that male students tend to have higher probablity to cheat by copying a friend's homework than their female conterparts in any point of GPA. The tendency of this kind of probability does not accur in the other cheating behavior since the simulataneous effect of sex differeneces and academic is not significant. 


\section{Discussion}

It is commonly understood that academic cheating is the use of illegal actions since it is a shortcut to attain achievement in the study. ${ }^{26}$ Although the act is unacceptable, both morally and legally, it is easily found in almost any university or college. The current study find that almost all participants (more tha $90 \%$ ) have experienced, at least one form of cheating behaviors, in the last year of their study at the university. Actually, this finding is not exclusive since it is a common occurrence in any country, in which studies find more than $45 \%$ of university students admit to frequently being dishonest. ${ }^{27}$ The finding also confirms previous study, ${ }^{28}$ which finds similar results.

Further finding of this study is that the overal number of participants involeved in cheating varies from one form of cheating behavior to another, ranging from $33 \%$ (using a friend's paper for fulfilling a course assignment) to $72.2 \%$ (citing references in writing without any modification). This finding is consistent with prior studies showing that many students have different ways in cheating. For example, Winardi, Mustikarini, and Anggraeni, ${ }^{29}$ found that theri respondents involved in various cheating behaviors in exam and assignment. Similar results were also found by Abdulghani et.al. ${ }^{30}$

The tendency to cheat may be influenced by contextual factors, in the extent that cheaters perceive or know that their peers cheat. ${ }^{31}$ They consider that the behavior is a normal practice in academic life. The permissive culture is developed through "a shift in the collective attitudes of the students, whereby (Spain)."

${ }^{26}$ Cladellas, Muntada, Martín, Gotzens, “Academic cheating and gender differences in Barcelona

${ }^{27}$ Harding, Mayhew, Finelli and Carpenter, "The Theory of Planned Behavior as a Model of Academic Dishonesty in Engineering and Humanities Undergraduates."

${ }^{28}$ Hadjar, "The Effect of Religiosity and Perception on Academic Cheating among Muslim Students in Indonesia."

${ }^{29}$ Rijadh Djatu Winardi, Arizona Mustikarini, Maria Azalea Anggraeni, "Academic Dishonesty Among Accounting Students: Some Indonesian Evidence," Jurnal Akuntansi dan Keuangan Indonesia 14, no. 2 (2017): 142-164.

${ }^{30}$ Hamza Mohammad Abdulghani, Shafiul Haque, Yousef Abdullah Almusalam, Saleh Lafi Alanezi, Yazeed Abdulaziz Alsulaiman, Mohammad Irshad, Nehal Khamis, "Self-reported cheating among medical students: An alarming finding in a cross-sectional study from Saudi Arabia," PLoS ONE 13, no. 3 (2018): 1-18, https://doi.org/10.1371/journal.pone.0194963.

${ }^{31}$ D.L. McCabe, K.D. Butterfield, and L.K. Trevino, Cheating in college: Why Students Do It and What Educators Can Do about It (Baltimore, MD: John Hopkins University Press, 2012), 102. 
cheating is increasingly viewed as less blameable and morally wrong the more often individual students perceive that their peers cheat." Moreover, the contextual conditions of the school can increase a student's incentives to cheat that have been influenced by the family.32 Students are more likely to cheat "when they perceive the risk of being detected as slight, and when the consequences of potential detection are regarded as low." ${ }^{33}$ It is also likely that students' cheating is due to previous experience, since there are few students who start cheating in entering higher education. ${ }^{34}$ Previous studies find that those who cheat in college also cheat during their study in high school. That is, the intensity of cheating in coolege is highly dependent on their experience in previous education.

The findings of this study make an important contribution to the literature on the relation of sex differences and academic performance with cheating behaviors among a specific population - Muslim students at Islamic univeristy. It also contribute to the higher education literature by highlighting that male and female students hve differences in intensity in some cheating behaviors and also similarity in some others.

Based on the findings of this study, it puts forward recommendations to create awareness amongst the students regarding cheating and plagiarism policies and provide guidelines to combat cheating in institutions of higher education.

\section{E. Conclusion}

The main purpose of this study is to examine the effect of sex differences and academic performance on the likelihood of cheating behaviors among students at Islamic state university. It is found that the effects of both explanary variables are not always consistent acrross different cheating behaviors. Separately from other variables, sex difference is a asignificant predictor for copying a friend's homework, making a cheat sheet for an exam, and copying a

${ }^{32}$ L.E. Nilsson, A. Eklöf, and T. Ottosson, "Cheating as a preparation for reality,” a paper presented in 32nd Congress of the Nordic Educational Research Association (NERA), Reykjavik, Iceland, 2004.

${ }^{33}$ Timothy 0. Bisping, Hilde Patron, and Kenneth Roskelley, "Modeling Academic Dishonesty: The Role of Student Perceptions and Misconduct Type," The Journal of Economic Education 39, no. 1 (2008): 4-21, https://doi.org/10.3200/JECE.39.1.4-21

${ }^{34}$ Hamani, Chalghaf, Maaloul, and Azaiez, "The Exam Cheating among Tunisian Students of the Higher Institute of Sport and Physical Education of Sfax." 
cheat sheet in an exam, but not for other cheating behaviors. While academic achievement is significant only in predicting students' cheating by copying a friend's homework, making a cheating sheet for an exam, and copying a cheating sheet in an exam. Simultaneously, the effect of both explanary variables is only significant on likelihood of cheating by copying a friend's homework. Male students are consitenly more likely to copy a friend's homework accros different levels of academic achievement than their female counterparts, although the tendency to cheat decreases as their academic achievement increases. Both are simultaneously not significant in predicting the likelihood of cheating by doing other cheating behaviors.[s]

\section{References}

Abdulghani, Hamza Mohammad, Shafiul Haque, Yousef Abdullah Almusalam, Saleh Lafi Alanezi, Yazeed Abdulaziz Alsulaiman, Mohammad Irshad, and Nehal Khamis. "Self-reported cheating among medical students: An alarming finding in a cross-sectional study from Saudi Arabia." PLoS ONE 13, no. 3 (2018): 1-18, https://doi.org/10.1371/journal.pone.0194963

Aşkar, Petek, Yasemin Koçak Usluel, and Filiz Mumcu. "Logistic Regression Modeling for Predicting Task-Related ICT Use in Teaching." Educational Technology and Society 9, no. 2 (2006): 141-151.

Bispingm Timothy O., Hilde Patron, and Kenneth Roskelley. "Modeling Academic Dishonesty: The Role of Student Perceptions and Misconduct Type." The Journal of Economic Education 39, no. 1 (2008): 4-21, https:// doi.org/10.3200/JECE.39.1.4-21

Bruggeman, Elizabeth Leistler and Kathleen J. Hart. "Cheating, Lying, and Moral Reasoning by Religious and Secular High School Students." The Journal of Educational Research 89, no. 6 (1996): 340-344.

Burrus, Robert T., Kim Marie McGoldrick and Peter W. Schuhmann. "Selfreports of student cheating: Does a definition of cheating matter?" The Journal of Economic Education 38, no. 1 (2007): 3-16.

Callahan, David. The Cheating Culture: Why More Americans are Doing More to Get Ahead. Orlando: Harcourt, 2005. 
Cladellas, Ramon. Mercè Clariana Muntada, Badia Martín, and Concepción Gotzens. "Academic Cheating and Gender Differences in Barcelona (Spain)," Summa Psicológica UST 10, no. 1 (2013): 65-72, https://doi.org/10.18774/ 448x.2013.10.37

Decoo, W. "How to Break that Cheating Art." Times Higher Education Supplement, 2002, February, 1526, 1.

Finn, Kristin Voelkl and Michael R. Frone. "Academic Performance and Cheating: Moderating Role of School Identification and Self-Efficacy." The Journal of Educational Research 97, no. 3 (2004): 115-121, https://doi.org/ 10.3200/JOER.97.3.115-121.

Hadjar Ibnu. W-Stats: Program Aplikasi Statistik Walisongo. Semarang: UIN Walisongo, 2016.

- - . "The Effect of Religiosity and Perception on Academic Cheating among Muslim Students in Indonesia." Journal of Education and Human Development 6, no. 1 (2017): 139-147, https://doi.org/10.15640/ jehd.v6n2a15

-_- Statistik untuk Ilmu Pendidikan, Sosial, dan Humaniora. Bandung: Rosda Karya, 2019.

Hamani, Jaouhar, Nasr Chalghaf, Habib Maaloul, and Fairouz Azaiez. "The Exam Cheating among Tunisian Students of the Higher Institute of Sport and Physical Education of Sfax," Journal of Humanities and Social Science 15, no. 6 (2013): 90-95.

Harding, Trevor S., Matthew J. Mayhew, Cynthia J. Finelli, and Donald D. Carpenter, "The Theory of Planned Behavior as a Model of Academic Dishonesty in Engineering and Humanities Undergraduates." Ethics \& Behavior 17, no. 3 (2007): 255-279, https://doi.org/10.1080/10508420701519239

IBM Corp. IBM SPSS Statistics for Windows, Version 22.0. Armonk, NY: IBM Corp, 2013.

Jensen, Lene Arnett, Jeffrey Jensen Arnett, Sue S. Feldman, and Elizabeth E. Cauffman. "It's Wrong, but Everybody Does It: Academic Dishonesty among High School and College Students." Contemporary Educational Psychology 27, no. 2 (2002): 209-28, https://doi.org/10.1006/ceps.2001.1088 
Ibnu Hadjar

Klein, Helen A., Nancy M. Levenburg, Marie McKendall, and William Mothersell. "Cheating during the College Years: How Do Business School Students Compare?" Journal of Business Ethics 72, no. 2 (2007): 197-206.

Lang, J. M. Cheating Lessons: Learning from Academic Dishonesty. Cambridge: Harvard University Press, 2013.

Lento, Camillo, Naqi Sayed, \& Merridee L. Bujaki. “Perceptions of Student Academic Dishonesty by Male and Female Accounting Faculty: Incidents and Responses," a paper presented at Canadian Academic Accounting Association (CAAA) Annual Conference, 2016, in SSRN: https:// ssrn.com/abstract=2713952 or http://dx.doi.org/10.2139/ssrn. 2713952

Marsden, Helen, Marie Carroll and James T. Neill. "Who cheats at university? A selfreport study of dishonest academic behaviours in a sample of Australian university students," Australian Journal of Psychology 57, no. 1 (2005): 1-10, https://doi.org/10.1080/00049530412331283426

McCabe, D.L, K.D. Butterfield, and L.K. Trevino. Cheating in college: Why Students Do It and What Educators Can Do about It. Baltimore, MD: John Hopkins University Press, 2012.

Moon, Jenny. Academic dishonesty, plagiarism and cheating: A self-instruction unit for postgraduate students, 2006, accessed on October 22, 2018, in http://wwwold.hud.ac.uk/schools/hhs/teaching_learning/plagiarism_han dout3.pdf

Niiya, Yu, Robert Ballantyne, Michael S. North, and Jennifer Crocker. "Gender, Contingencies of Self-Worth, and Achievement Goals as Predictors of Academic Cheating in a Controlled Laboratory Setting," Basic and Applied Social Psychology 30, no. 1 (2008): 76-83.

Nilsson, L.E. Nilsson, A. Eklöf, and T. Ottosson. "Cheating as a preparation for reality," a paper presented in 32nd Congress of the Nordic Educational Research Association (NERA), Reykjavik, Iceland, 2004

Rettinger, David and Agustus Jordan. "The Relations Among Religion, Motivation, and ollege Cheating: A Natural Experiment." Ethics \& Behavior 15, no. 2 (2005): 107-129, https://doi.org/10.1207/s15327019eb1502_2

Starovoytova, Diana and Saul Namango. "Factors Affecting Cheating-Behavior at Undergraduate-Engineering," Journal of Education and Practice 7, no. 31 (2016): 66. 
Witherspoon, Michelle, Nancy Maldonado, and Candace H. Lacey. "Academic Dishonesty of Undergraduates: Methods of Cheating," Paper presented at the Annual Meeting of the American Educational Research Association, May 2010, Denver, Colorado.

Whitley Jr., Bernard E. "Factors Associated with Cheating among College Students: A Review," Research in Higher Education 39, no. 3 (1998): 235-274.

Winardi, Rijadh Djatu, Arizona Mustikarini, and Maria Azalea Anggraeni. "Academic Dishonesty among Accounting Students: Some Indonesian Evidence." Jurnal Akuntansi dan Keuangan Indonesia 14, no. 2 (2017): 142164. 
This page intentionally left blank 